\title{
Among the rice fields, Japan tests the international waters
}

Tokyo. Japan's first big test of how well it handles the internationalization of science is unfolding in the middle of a rice-farming region $100 \mathrm{~km}$ northeast of Tokyo. Over the coming months, dozens of researchers from Europe, the United States and Russia will arrive at the Naka fusion research establishment to operate Japan's contribution to the International Thermonuclear Experimental Reactor (ITER) project. Naka is one of three co-centres - the others are in Garching, Germany and San Diego, California - for the six-year, \$1 billion engineering design phase of ITER (see Nature 358, 269; 1992).

Naka was chosen by Japan's Science and Technology Agency (STA) because Japan's JT-60 Tokamak is located there and there are many scientists and engineers at the fusion establishment with expertise in the design and building of superconducting magnets, one of the key components of ITER that the Naka group will be responsible for designing. And at present there is plenty of room for foreigners. Michel Huguet, deputy director of the design phase for the European Communities and head of the Naka co-centre; Britain's Barry Green; and R.O. Thome of the United States are the only three non-Japanese researchers now working at Naka. Over the next two years, however, they will be joined by more than 40 scientists from Europe, the United States and Russia as the engineering design phase gets into full swing.

That influx will overwhelm the Japanese contingent, making Naka the first example in Japan of a truly international research centre dominated and directed by non-Japanese. Japan's lack of experience in operating such an international organization is already beginning to show.

One immediate problem is the lack of an international school for the children of the non-Japanese researchers. The closest established schools

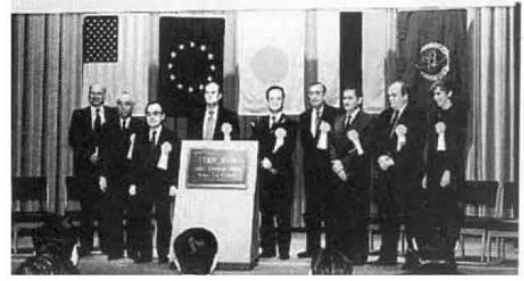
Above: An aerial view of
the Naka Fusion Research
Establishment.

Left: Opening ceremonies for the Naka centre were held in October.

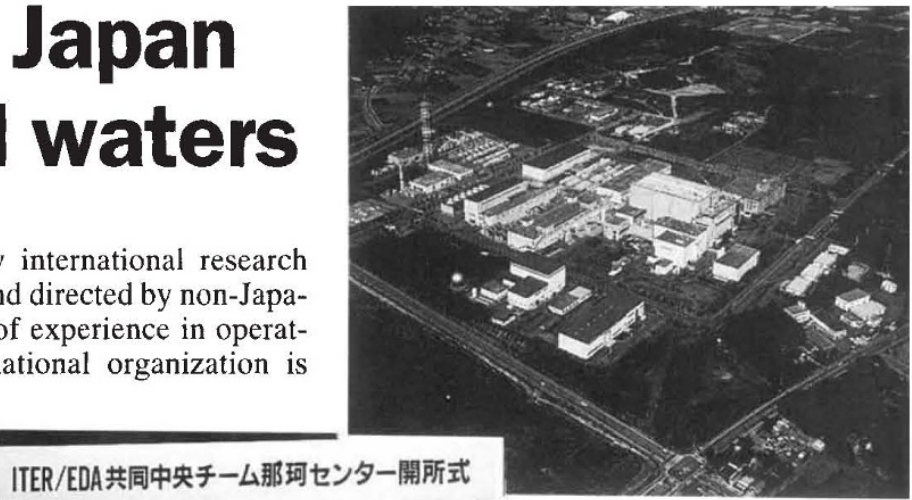

are $100 \mathrm{~km}$

away in Tokyo, although Tsukuba science city, about halfway between Tokyo and Naka, does have a fledgling international elementary school for a handful of young children (see below).

STA and the Japan Atomic Energy Research Institute, which runs the Naka establishment, have hurriedly begun building a small international school at Naka to be operated as a branch of St Mary's International School of Tokyo. However, the school, scheduled to open in a few months, will enrol children only up to 15 years of age. Older children must attend international schools in Tokyo and stay with Japanese families if their parents choose to live in Naka.

One of the non-Japanese researchers already at Naka has a teenage daughter.

\section{Tsukuba school paves the way}

Tokyo. After years of lobbying by foreign scientists, Tsukuba science city northeast of Tokyo at last has an international school to educate some of the children of the city's large community of foreign scientists.

Tsukuba International School, which opened in September, is only a small start a private elementary school with about a dozen children aged 6 to 11 and one British teacher. Nevertheless, it is a significant step forward for Japan, where government science policy makers repeatedly call for "internationalization" but seldom provide or even encourage the necessary local infrastructure.

There are about 150 foreign school-age children in Tsukuba and the number is growing each year. Until now, these children have had to attend local Japanese schools, which pose problems for older children because the classes are in Japanese.

The school was started by a small local group of foreign and Japanese volunteers with money from private companies and one government organization. A local cram school provided a classroom at token rent.

The effort has taken three years and one large hurdle remains. The school has not existed long enough to be granted tax-free status as a gakko hojin (school foundation) from the local prefectural education board under the ministry of education; as a result, companies are reluctant to contribute to it because their donations are taxed.

Another problem is that scientists at public research institutes cannot afford its fees. The school has introduced some scholarships but, again, funds are limited because it lacks gakko-hojin status.

Rather than have his daughter live separately from the family, the researcher has decided to live in Tokyo and to commute to Naka.

The Japanese are doing their best to accommodate the foreign researchers. Twenty single-family houses are being built in Naka, and unmarried scientists will be housed in brand-new apartments that are very spacious by Japanese (and even Western) standards. Furthermore, the foreign scientists will not have to pay the expensive fees for their children to attend international school.

Another problem concerns support personnel. Under the agreement signed in July for the engineering design phase, Japan has to provide several 'designers' at Naka. But there has been disagreement about the requisite skills of such designers. Japan at first offered computer-assisted design (CAD) operators who can handle data only in Japanese and who have no ability to design a thermonuclear reactor. The other ITER partners want designers with backgrounds in mechanical engineering and an ability to communicate in English.

Shin Aoyama, director for fusion energy at STA, says CAD designers with those skills are very hard to find in Japan. In the West, suitable designers can be found for moderate salaries among people without a university-level education. But in Japan such designers are scarce and command high salaries. This week, when the ITER Council meets in Moscow, Japan is expected to give a firm commitment to provide the necessary level of designers.

So things at Naka are moving in the right direction, says one organizer of ITER. But he says that, despite their goodwill, the Japanese do not fully seem to realize that the Naka centre must be organized along internationally established lines and not on Japanese terms because the majority of researchers will be non-Japanese.

David Swinbanks 